\title{
Pengembangan Kegiatan MINI-LAB pada Topik Ekologi dan Lingkungan Untuk Siswa Kelas X SMA
}

\author{
Verronicha Crysty ${ }^{1}$, Binari Manurung ${ }^{2}$, Syarifuddin ${ }^{3}$, \\ Pascasarjana Universitas Negeri Medan,Medan ${ }^{1 *}$ \\ verronichacrysty@gmail.com
}

\begin{abstract}
This research aimed to develop a Mini-Lab on ecology and environment topics based on scientific literacy and local potential of North Sumatera which is feasible empirically. Feasibility of learning material is obtained through validation of content experts, design expert, assessment from biology teacher and students' response to product that developed. This research and development used Borg and Gall model. However this study was limited to preliminary field testing only. Data validation and the questionnaire responses of teachers and students were analyzed descriptively qualitative. The result showed that according to content experts, the feasibility of product content was very good with average percentage score $93.32 \%$. Feasibility of Mini-Lab's design that has been developed based on design expert was also very good with a percentage score of $91.66 \%$. Result of biology teacher assessment on Mini-Lab activity on ecology and environment topics for X grade of senior high school students was developed with $93.75 \%$ (very good). Students' response to the preliminary field testing individual testing is $80.35 \%$ (good), small group trial $84.52 \%$ (very good) and big group $91.38 \%$.(very good).
\end{abstract}

Keywords : Mini-Lab, ecology and environmental, science literation

\section{PENDAHULUAN}

Ekologi dan Lingkungan salah satu materi dalam pelajaran biologi yang erat kaitannya dengan kehidupan sehari-hari. Manusia memiliki berbagai potensi dalam mengubah lingkungan sehingga mengakibatkan perubahan sistem dalam lingkungan hidup. Populasi manusia yang semakin meningkat cenderung bersaing dalam upaya memenuhi kebutuhan hidup yang seringkali mengubah kondisi lingkungan secara fisik ataupun kimiawi, contohnya pada bidang pertanian penggunaan pestisida secara berlebihan dapat mengakibatkan kepunahan atau penurunan populasi organisme, terganggunya keseimbangan ekosistem, tercemarnya aliran sungai dengan limbah beracun, serta kerusakan dan pencemaran tanah (Campbell, 2004). Oleh sebab itu, dalam mempelajari materi ekologi dan lingkungan tidak cukup hanya dengan menghafal fakta, namun harus menemukan sendiri fakta tersebut.

Berdasarkan hasil angket pra-penelitian yang dilaksanakan pada bulan Januari 2016 di SMA Negeri 4 Binjai dan SMA Negeri 6 Binjai, siswa mengaku mengalami kesulitan dalam belajar biologi khususnya materi ekologi dan lingkungan dikarenakan kurangnya bahan ajar yang disediakan oleh sekolah, mereka hanya mendapatkan buku BSE (hardcopy) yang dinilai kurang menarik dan tidak memuat kasus yang dekat dengan kehidupan sehari-hari siswa sehingga siswa hanya sekedar menghapal fakta dan tidak terlibat langsung dalam menemukan fakta terkait topik.

Salah satu cara untuk belajar pada materi perubahan lingkungan didasarkan pada kegiatan penemuan/investigasi yang dilakukan oleh peserta didik sendiri (Irwandi, 2009). Pemrosesan informasi untuk mendapatkan pengetahuan baru dapat dilakukan dengan cara mengumpulkan sumber data/informasi dari lingkungan, mengorganisir data/informasi, memecahkan masalah, serta menemukan konsep melalui pemecahan masalah dengan melibatkan keteramilan proses sains (Ahmadi dan Amri, 2014). Berdasarkan penjelasan tersebut, maka dalam mempelajari materi ekologi dan lingkungan diharapkan lebih menekankan pada pengalaman diri siswa secara langsung kegiatan Mini-Lab yang mencakup kegiatan observasi, eksperimen, atau keterampilan sains lainya untuk mendapatkan informasi yang rasional dan dapat diuji kebenarannya sehingga diperoleh pengetahuan dan pemahaman yang lebih bermakna serta 
dapat menunjang keberhasilan belajar siswa (Sujarwanta, 2012).

Untuk mendukung kegiatan pembelajaran yang efektif diperlukan penguatan dari sumber belajar, salah satunya yaitu Kegiatan Mini-Lab yang mampu membantu peserta didik dalam mengkonstruksi pengetahuan melalui kegiatan menginvestigasi dan melatihkan berpikir kritis melalui pemahaman yang didasarkan pada pengalaman diri siswa secara ilmiah. Oleh sebab itu, Mini-Lab harus dapat memfasilitasi siswa dalam menemukan pengetahuan dan fakta terkait Ekologi dan Lingkungan melalui kegiatan investigasi, observasi guna melatih keterampilan berpikir peserta didik untuk memecahkan masalah disekitar mereka. Tujuan penelitian ini yaitu mengembangkan sebuah Kegiatan Mini-Lab topik Ekologi dan Lingkungan untuk siswa kelas X SMA yang layak secara empiris.

\section{METODE PENELITIAN}

Penelitian ini merupakan penelitian pengembangan, di mana perangkat yang dikembangkan adalah Kegiatan Mini-Lab dengan model pengembangn Borg and Gall namun hanya dilakukan sampai tahap uji lapangan terbatas saja. Validasi yang dilakukan oleh 2 dosen ahli materi, 1 dosen ahli desain, dan 3 guru biologi dan 40 siswa SMA Kelas XI IPA bertujuan untuk mengetahui kelayakan produk yang dikembangkan secara teoritis. Instrumen yang digunakan adalah lembar validasi yang meliputi aspek kelayakan isi materi, kelayakan penyajian dan kelayakan desain. Metode pengumpulan data dalam penelitian ini adalah dengan metode pengumpulan hasil validasi, kemudian data yang didapatkan dianalisis secara deskriptif kualitatif.

\section{HASIL DAN PEMBAHASAN}

Berdasarkan hasil validasi yang telah dilakukan oleh ahli materi, ahli desain dan guru biologi untuk mengetahui kelayakan Mini-Lab secara teoritis berdasarkan kelayakan isi materi, kelayakan penyajian, kelayakan desain, maka diperoleh hasil sebagai berikut:

\section{Penilaian Kelayakan oleh Ahli Materi}

Penilaian pada aspek kelayakan Mini-Lab topik Ekologi dan Lingkungan oleh validator ahli materi mengacu pada 2 komponen utama, yakni: 1)Kelayakan isi dan 2) Kelayakan Penyajian. Aspek kelayakan isi produk dinyatakan sangat layak. Semua sub komponen kelayakan isi yaitu kesesuaian materi dengan KI dan KD; Sains sebagai cara menginvestigasi; dan Sains sebagai cara berpikir memiliki kriteria "sangat baik"dengan perolehan skor persentasi kelayakan isi sebesar $92,76 \%$, seperti yang terlihat pada Tabel 1 dan Gambar 1.

Tabel 1. Penilaian Kelayakan Mini-Lab untuk siswa kelas X SMA oleh Ahli materi

\begin{tabular}{|c|c|c|c|c|c|c|c|c|}
\hline \multirow{2}{*}{ Komponen } & & \multirow{2}{*}{ Sub Komponen } & \multirow{2}{*}{$\begin{array}{c}\text { Jumlah } \\
\text { item }\end{array}$} & \multicolumn{2}{|c|}{ Validator } & \multirow{2}{*}{$\begin{array}{l}\text { Total } \\
\text { Skor }\end{array}$} & \multirow{2}{*}{$\%$} & \multirow{2}{*}{ Kriteria } \\
\hline & & & & 1 & 2 & & & \\
\hline \multirow{4}{*}{$\begin{array}{c}\text { Kelayakan } \\
\text { isi }\end{array}$} & 1. & $\begin{array}{l}\text { Kesesuaian isi } \\
\text { terhadap KI-KD }\end{array}$ & 4 & 16 & 14 & 30 & 93,75 & Sangat Baik \\
\hline & 2. & $\begin{array}{l}\text { Sains sebagai cara } \\
\text { menginvestigasi }\end{array}$ & 6 & 21 & 21 & 42 & 87,50 & Sangat Baik \\
\hline & & $\begin{array}{l}\text { Sains sebagai cara } \\
\text { berpikir }\end{array}$ & 8 & 29 & 32 & 61 & 95,31 & Sangat Baik \\
\hline & & Total & & & 38 & 282 & 92,76 & at Baik \\
\hline
\end{tabular}

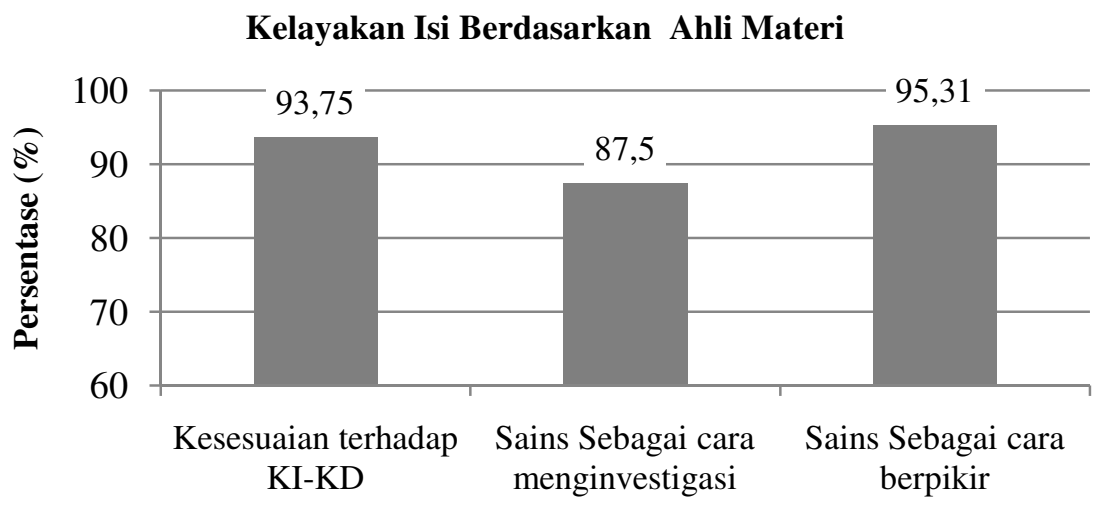


Gambar 1. Diagram penilaian kelayakan isi Mini-Lab untuk siswa kelas X SMA berdasarkan Ahli Materi

Hal ini dikarenakan dalam penyusunan Mini-Lab mengacu pada tujuan pembelajaran serta uraian materi yang telah sesuai dengan kompetensi inti (KI) dan kompetensi dasar (KD), sebagaimana halnya persyaratan untuk penyusunan sumber belajar yang baik. Kariem (2013) menyatakan bahwa dalam menyusun sumber belajar perlu memperhatikan kurikulum.

Mini-Lab ini yang dikembangkan dan disusun berdasarkan syarat-syarat penyusunan sumber belajar yang baik sesuai menurut Depdiknas (2004) yang diawali dengan menganalisis kurikulum, menyusun peta kebutuhan, menentukan judul produk yang akan dikembangkan, dan kemudian mulai menulis draft Mini-Lab Ekologi dan Lingkungan.

Kelayakan penyajian termasuk dalam kategori sangat layak. Penilaian kelayakan penyajian ini dibagi menjadi dua kriteria yaitu teknik penyajian dan penyajian pembelajaran.

Tabel 2. Penilaian Kelayakan Mini-Lab untuk siswa kelas X SMA berdasarkan Ahli Materi

\begin{tabular}{|c|c|c|c|c|c|c|c|}
\hline \multirow[b]{2}{*}{ Komponen } & \multirow[b]{2}{*}{ Sub Komponen } & \multirow{2}{*}{$\begin{array}{c}\text { Jumlah } \\
\text { item }\end{array}$} & \multicolumn{2}{|c|}{ Validator } & \multirow{2}{*}{$\begin{array}{l}\text { Total } \\
\text { Skor }\end{array}$} & \multirow{2}{*}{$\%$} & \multirow[b]{2}{*}{ Kriteria } \\
\hline & & & $\mathbf{1}$ & 2 & & & \\
\hline & Tehnik Penyajian & 3 & 11 & 12 & 23 & 95.83 & Sangat Baik \\
\hline \multicolumn{8}{|l|}{ Kelayakan } \\
\hline Penyajian & $\begin{array}{l}\text { Penyajian } \\
\text { Pembelajaran }\end{array}$ & 3 & 12 & 12 & 24 & 100 & Sangat Baik \\
\hline \multicolumn{2}{|c|}{ Total Skor } & 6 & 23 & 24 & 47 & 97.91 & Sangat Baik \\
\hline
\end{tabular}

Berdasarkan Tabel 2. Diatas, diperoleh data bahwa teknik penyajian produk termasuk kedalam kriteria "sangat baik" dengan perolehan skor persentasi rata-rata kelayakan sebesar 97,91\%. Hal ini menunjukkan bahwa Mini-Lab ini sudah dituliskan dalam urutan yang sesuai dan saling berhubungan, serta dibantu dengan penggunaan bahasa yang baik dan mudah dipahami siswa karena bahasa yang digunakan dalam produk sesuai dengan tingkat perkembangan siswa. Trianto (2010) menyatakan bahwa bahasa yang digunakan dalam menyusun kalimat pada bahan ajar harus jelas, sederhana, dan sesuai dengan kemampuan siswa.

\section{Penilaian Kelayakan oleh Ahli Desain}

Penilaian pada aspek kelayakan desain Mini-Lab topik Ekologi dan Lingkungan oleh validator ahli materi mengacu pada 3 komponen utama, yakni: (1) Kelayakan Penyusunan Layout, (2) Kelayakan Tipografi dan (3) Kelayakan Ilustrasi isi.

Table 3. Penilaian Kelayakan Mini-Lab untuk siswa kelas X oleh ahli desain

\begin{tabular}{|c|c|c|c|c|c|c|}
\hline Komponen & Sub Komponen & $\begin{array}{c}\text { Jumlah } \\
\text { item }\end{array}$ & Validator Desain & $\begin{array}{l}\text { Total } \\
\text { Skor }\end{array}$ & $\%$ & Kriteria \\
\hline \multirow{3}{*}{$\begin{array}{l}\text { Desain Konten } \\
\text { Mini-Lab }\end{array}$} & $\begin{array}{l}\text { Penyusunan lay- } \\
\text { out }\end{array}$ & 6 & 20 & 20 & 83,33 & Sangat Baik \\
\hline & Tipografi & 5 & 20 & 20 & 100 & Sangat Baik \\
\hline & Ilustrasi Isi & 3 & 11 & 11 & 91.67 & Sangat Baik \\
\hline \multicolumn{2}{|c|}{ Total skor } & 14 & 51 & 51 & 91.66 & Sangat Baik \\
\hline
\end{tabular}

Berdasarkan hasil validasi ahli desain pada Tabel 3, dipaparkan bahwa kelayakan aspek desain Mini-Lab juga dinilai sangat baik dan layak dengan skor persentase rata-rata sebesar 91,66\%. Kelayakan aspek desain tersebut diperoleh karena tipe huruf dan ukuran yang digunakan dalam menyusun produk mudah untuk dibaca, dipahami, jelas, serta ukuran yang sesuai. Sesuai dengan pedoman penyusunan bahan ajar cetak oleh Depdiknas (2004) yang menyatakan bahwa dalam penyusunan bahan ajar cetak sangat penting memperhatikan kemenarikan bahan ajar dan kemudahan untuk dibaca.

Mini-Lab juga dikemas dengan menarik, kertas sampul menggunakan kertas art paper 260 gram dan dilaminasi sehingga terlihat mengkilap dan tahan air, kertas Mini-Lab menggunakan kertas ukuran A4 100 gram sehingga tidak tembus jika digunakan timbalbalik.

Selain itu, kualitas gambar (foto) yang digunakan jelas dan menarik dan representatif untuk penyampaian konsep. Menurut 
Komalasari (2011) suatu gambar atau foto dapat memberikan gambaran nyata yang menunjukkan objek sesungguhnya, memberikan makna pembelajaran yang lebih hidup dan tepat dibanding dengan kata-kata sehingga merangsang kemampuan berpikir siswa. Dengan demikian, sumber belajar akan berpengaruh positif terhadap kegiatan pembelajaran, terutama pada peningkatan motivasi belajar siswa. Hal tersebut juga didukung dengan hasil validasi ahli desain terhadap ilustrasi/gambar isi produk tergolong dalam kriteria "sangat baik".

\section{Penilaian Kelayakan oleh Guru Biologi}

Dari hasil penilaian yang dilakukan oleh 3 orang guru biologi dengan mengacu pada beberapa indikator dalam instrumen angket yang digunakan, diperoleh respon positif dimana Mini-Lab topik Ekologi dan Lingkungan dinyatakan telah tergolong dalam kriteria sangat layak. Hal ini diperoleh sebab seluruh indikator penilaian kelayakan telah memiliki kriteria "sangat baik"dengan perolehan skor persentasi rata-rata sebesar $93,33 \%$, seperti yang terlihat padaTabel 4 dan Gambar 2.

Tabel 4. Respon Guru Biologi terhadap Kelayakan Kegiatan Mini-Lab

\begin{tabular}{clcccccc}
\hline \multirow{2}{*}{ No Indikator } & \multicolumn{3}{c}{ Guru Biologi } & \multirow{2}{*}{$(\boldsymbol{\%})$} & \multirow{2}{*}{ Kriteria } \\
\cline { 3 - 5 } & & $\mathbf{1}$ & $\mathbf{2}$ & $\mathbf{3}$ & & \\
\hline 1 & Memiliki tujuan pembelajaran & 4 & 3 & 4 & 91,67 & Sangat Baik \\
2 & $\begin{array}{l}\text { Sesuai dengan tingkat perkembangan siswa } \\
\text { Memotivasi siswa untuk berkomunikasi, }\end{array}$ & 4 & 4 & 4 & 100 & Sangat Baik \\
3 & $\begin{array}{l}\text { Merinteraksi dan berkolaborasi } \\
4\end{array}$ & 3 & 3 & 83,33 & Sangat Baik \\
5 & Menstimulasi siswa untuk berfikir kritis & 3 & 4 & 4 & 91,67 & Sangat Baik \\
\hline & Sesuai dengan contoh/ isu dikehidupan sehari-hari & 4 & 4 & 4 & 100 & Sangat Baik \\
\hline
\end{tabular}

\section{Penilaian Kelayakan oleh Siswa}

Selain memperhatikan penilaian dari validator ahli materi dan ahli desain, serta guru biologi, Produk juga dinilai dan ditanggapi siswa pada uji coba lapngan terbatas. Uji lapangan terbatas dilakukan melalui 3 tahapan yakni; uji perorangan dengan 3 siswa, uji kelompok kecil dengan 9 siswa dan uji kelompok besar dengan 40 siswa.

Dari hasil penilaian pada uji lapangan terbatas, seluruh indikator dalam instrumen angket yang digunakan menunjukkan respon positif dari siswa terhadap produk Mini-Lab topik Ekologi dan Lingkungan. Hal ini dapat dilihat pada gambar 3, dimana seluruh indikator penilaian kelayakan telah memiliki kriteria "sangat baik" atau "layak" dengan perolehan skor persentasi rata-rata pada uji perorangan sebesar "77,08" (baik), uji kelompok kecil 91,66 (sangat baik) dan meningkat pada uji kelompok besar dengan perolehan skor persentase rata-rata sebesar 93,44\%.

\section{Respon Siswa Pada Uji Lapangan Terbatas}

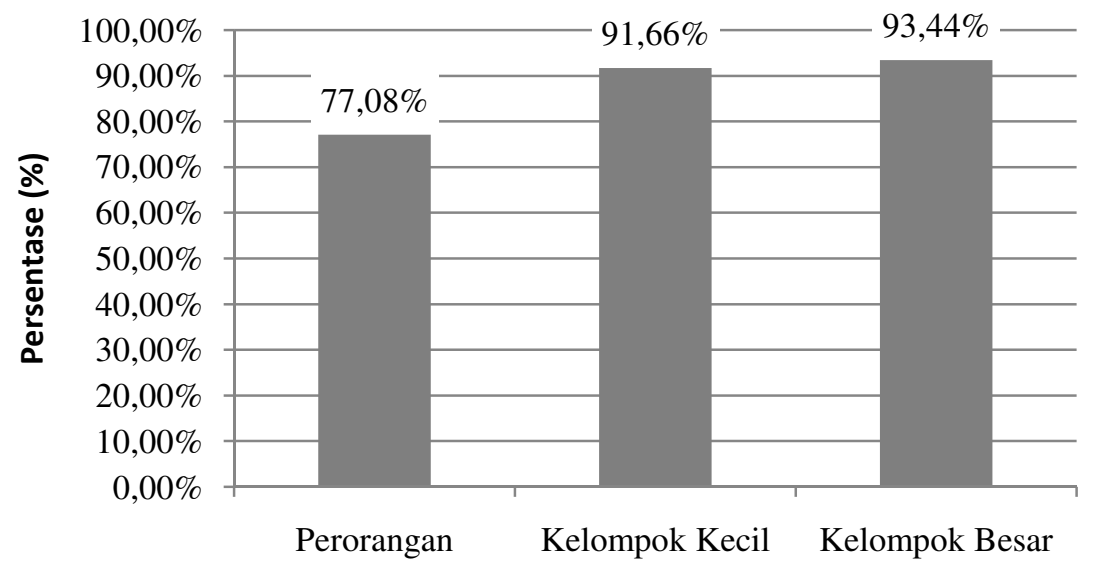

Gambar 2. Respon siswa pada uji lapangan terbatas terhadap kelayakan produk 
Mini-Lab mampu memotivasi peserta didik untuk merespon materi dan juga mendorong siswa untuk berpikir kritis, aktif dan kreatif karena penyajian bersifat dialogis, komunikatif, lugas dan interaktif serta melibatkan siswa aktif beraktivitas. Tidak hanya itu, pada tabel 5 terlihat bahwa mini-lab dinilai telah mencakup kasus-kasus yang ada dikehidupan sehari-hari siswa sehingga membuat proses belajar lebih menyenangkan.

Tabel 5. Hasil penilaian uji lapangan terbatas pada kelompok besar untuk mengetahui kelayakan MiniLab topik Ekologi dan Lingkungan untuk siswa kelas X SMA

\begin{tabular}{clcc}
\hline No & \multicolumn{1}{c}{ Indikator } & Persentase (\%) & Kriteria \\
\hline 1 & Memotivasi untuk belajar & 93,13 & Sangat Baik \\
2 & Instruksi mudah untuk dipahami & 91,88 & Sangat Baik \\
3 & Membantu siswa untuk mempelajari kasus di kehidupan & 96,25 & Sangat Baik \\
4 & sehari-hari & 92,50 & Sangat Baik \\
\hline & Membuat proses belajar menjadi lebih menyenangkan & $\mathbf{9 3 , 4 4}$ & Sangat Baik \\
\hline
\end{tabular}

Selain itu, tampilan Mini-Lab dianggap menarik bagi siswa karena desainnya terlihat bagus dan tidak berlebihan, dan berwarna terang dengan kertas yang tebal. Penampilan sangat penting dalam sebuah sumber belajar, karena siswa akan tertarik pada penampilan produk sebelum membaca isinya (Trianto, 2010).

\section{KESIMPULAN}

Kelayakan Kegiatan Mini-Lab topik Ekologi dan Lingkungan untuk siswa SMA kelas $\mathrm{X}$ yang telah dikembangkan menurut penilaian validator ahli materi, ahli desain, guru biologi dan siswa adalah sangat baik dan layak untuk digunakan pada pembelajaran biologi topik ekologi dan lingkungan pada siswa kelas $\mathrm{X}$. Persentase skor rata-rata penilaian ahli materi terhadap kelayakan Mini-Lab adalah 93,32\% (sangat baik), menurut ahli desain $91,66 \%$ (sangat baik), menurut guru 93,75\% (sangat baik), dan persentase skor respon siswa pada uji coba perorangan adalah $80,35 \%$ (baik), uji coba kelompok kecil $84,52 \%$ (sangat baik) dan uji coba kelompok besar 91,38\% (sangat baik).

\section{DAFTAR PUSTAKA}

Ahmadi, I., Amri, S., dan Elisah, T. 2012. Mengembangkan Pendidikan Berbasis Keunggulan Lokal. Jakarta: Prestasi Pustaka.

Arsyad, A. 2012. Media Pembelajaran. Jakarta: PT Raja Grafindo Persada.
Asmani, Ma'mur, J. 2012, Pendidikan Berbasis Keunggulan Lokal.Yogyakarta: DIVA Press.

Borg, Gall. 2003. Educational Research: An Introduction $4^{\text {th }}$ Edition. London: Longman Inc.

Depdiknas. 2004. Pedoman Penyusunan Lembar Kerja Siswa Dan Skenario Pembelajaran Sekolah Menengah Atas. Jakarta: Direktorat Jendral Pendidikan Dasar dan Menengah.

Hamalik, O. 2008. Proses Belajar Mengajar. Jakarta: PT Bumi Aksara.

Kariem, F., Elvyanti, S., Gunawan, Mulyana. Pengembangan Bahan Ajar TIK SMP Mengacu Pada Pembelajaran Berbasis Proyek. Invotec, 9 (2):117-128.

Kemdikbud. 2013. Kurikulum 2013, Sekolah Menengah Atas (SMA)/ Madrasah Aliyah (MA). Jakarta: Direktorat Jendral Pendidikan Dasar dan Menengah.

Komalasari, K. 2011. Pembelajaran Kontekstual Konsep dan Aplikasi. Bandung: PT Refika Aditama.

Peraturan Menteri Pendidikan dan Kebudayaan Republik Indonesia nomor 81 A Lampiran IV. 2013. Tentang Implementasi Kurikulum Pedoman Umum Pembelajaran. Jakarta.

Prastowo, A. 2011. Panduan Kreatif Membuat Bahan Ajar Inovatif, Jogjakarta: Diva Press.

Sajidan, 2013. Pembelajaran Biologi dengan Pendekatan Saintifik pada Implementasi Kurikulum 2013, Makalah disajikan dalam Seminar Nasional XI Pendidikan Biologi FKIP UNS.

Trianto. 2010. Mendesain Model Pembelajaran Inoatif-Progresif. Jakarta: Kencana Prenada Media Group. 